\title{
ANALISIS DAN PERANCANGAN APLIKASI SISTEM INFORMASI AUDIT MUTU INTERNAL DAN DOKUMENTASI PENJAMINAN MUTU PERGURUAN TINGGI
}

\author{
Ayu Yulia Safitri \\ 195100037P \\ Fakultas Komputer \\ ayuyulia.student@umitra.ac.id
}

\begin{abstract}
Perkembangan teknologi yang sangat pesat memberikan nilai lebih bagi perguruan tinggi untuk meningkatkan keamanan dan kemudahan dalam menyimpan informasi. Teknologi tidak hanya menggunakan data sistem informasi secara umum, tetapi juga membantu dalam proses audit internal. Perguruan tinggi dan pendidikan saat ini memerlukan penjamin mutu guna memastikan mutu pendidikan. Penerapan sistem penjaminan mutu yang sudah berjalan memerlukan proses audit internal guna memastikan proses mutu tetap berjalan. Internal audit memiliki peran penting dalam suatu manajemen, dimana pelaksanaan audit internal dilakukan dengan form-form audit dalam bentuk kertas maupun secara elektronik. Sehingga permasalahan di atas membutuhkan alat bantu dengan sedikit melakukan isian dan secara otomatis sistem akan menyalin semua kode yang sama berbasis paper list, mengolah dalam bentuk file presentasi (grafik), analisis data dan lainnya. Auditor dapat menambahkan atau mengurangi data dengan pengisian langsung pada menu klausa pertanyaan. Selain itu, auditor dapat langsung memberikan catatan temuan serta kapan departemen atau unit kerja dapat memberikan tanggapan terhadap temuan itu untuk diselesaikan dari segi manajemen historikal hasil audit yang akurat dan tersaji secara cepat, serta dapat dibandingkan antara hasil audit setiap departemen, setiap klausul maupun atas waktu. Hasil audit juga menyajikan performance setiap departemen dalam bentuk angka (ukuran kuantitatif). Selain itu, perangkat lunak dapat menyajikan record audit per auditor untuk membantu evaluasi, dan meningkatkan kompetensi auditor.
\end{abstract}

Kata kunci: auditor internal, penjamin mutu, paper list, manajemen historikal, record audit. 


\section{A. PENDAHULUAN}

Perkembangan Teknologi Informasi (TI) yang cepat memunculkan perangkat keras dan perangkat lunak dengan biaya murah. Perkembangan ini memunculkan berbagai macam aplikasi dan model pengelolaan terhadap TI. Berbagai perkembangan TI ini membuat banyak perusahaan mengalami pergeseran dari sistem manual ke komputerisasi sehingga penyimpanan data menjadi efesien, informasi yang up to date, dan cepat dalam penyajian informasi. Standar pengukuran internasional pada suatu organisasi yang dinamakan dengan International Standard Organization (ISO) tidak hanya pada perusahaan manufaktur saja tetapi dapat dilakukan di perguruan tinggi (PT). Suatu lembaga pendidikan memiliki faktor kontrol, informasi dan dokumentasi merupakan hal penting dan mempengaruhi terhadap kualitas suatu lembaga pendidikan tersebut. Salah satunya adalah aktivitas penjaminan mutu akademik di PT yang dilakukan suatu internal audit di setiap unit dan jurusan. Pelaksanaan audit dilakukan dengan standar guna mencapai tujuan audit yang telah ditetapkan sebelumnya.

Dalam lembaga pendidikan informasi tidak kalah pentingnya dengan informasi di dalam perusahaan. Informasi yang ada haruslah dilindungi. Salah satu informasi yang berpengaruh pada suatu kualitas pendidikan adalah informasi yang terdapat dalam internal audit, dimana internal audit pada PT lebih mengarah pada audit kendali mutu jurusan maupun setiap unit. Pengumpulan semua informasi yang berguna untuk melakukan penilaian terhadap mutu jurusan dan unit harus dilakukan melalui beberapa tahapan proses audit memerlukan waktu yang lama apabila dilakukan secara manual, seperti pembuatan pertanyaan audit, penentuan klausal, temuan yang menyebabkan tidak tercapai standar proses atau target, kapan perbaikan dari hasil temuan, pendokumentasian hasil temuan dan perbaikan temuan serta pendokumentasian dan pencarian informasi audit sebelumnya memerlukan waktu yang lama.

Untuk menjaga mutu jurusan dan unit tersebut, serta makin kompleksnya penjaminan mutu ke depan perlu dirancang sistem informasi yang dapat memberikan kemudahan dalam mengaudit dan memberikan informasi dengan dokumentasi yang lengkap terkait dengan proses yang ada dan dapat sebagai media sosialisasi terkait dengan proses mutu di PT tersebut.

\section{B. PEMBAHASAN / STUDI KASUS}

Pada bagian ini menjelaskan analisis proses bisnis yang dihasilkan, analisis perancangan DFD, rancangan kebutuhan program, disain dan relasi tabel, dan implementasi sistem informasi audit.

\section{Analisis Proses Bisnis yang Dihasilkan}

Hasil analisis proses audit di penjaminan mutu IBI Darmajaya dapat menyimpulkan dan merancang proses yang dijalankan sebagai acuan auditor dalam melakukan audit. Gambar 2 memperlihatkan proses bisnis yang terjadi pada bagian tim auditor, auditee dan top management.

\section{Analisis Perancangan DFD}

Analisis perancangan DFD berdasarkan masukan, proses dan keluaran yang diinginkan menurut proses audit serta kebutuhan dari internal audit dapat dilihat pada Gambar 1. Perancangan DFD ini digunakan sebagai landasan pembuatan program dan database sistem informasi audit dan dokumentasi yang dilakukan.

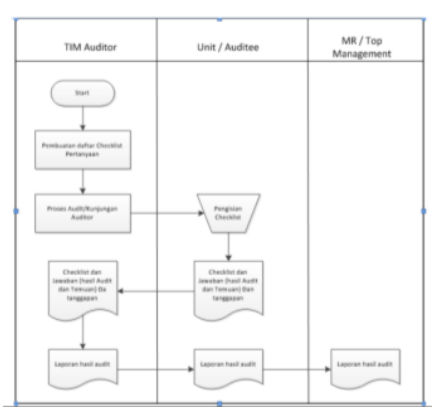

Gambar 1 Proses Bisnis yang berjalan 


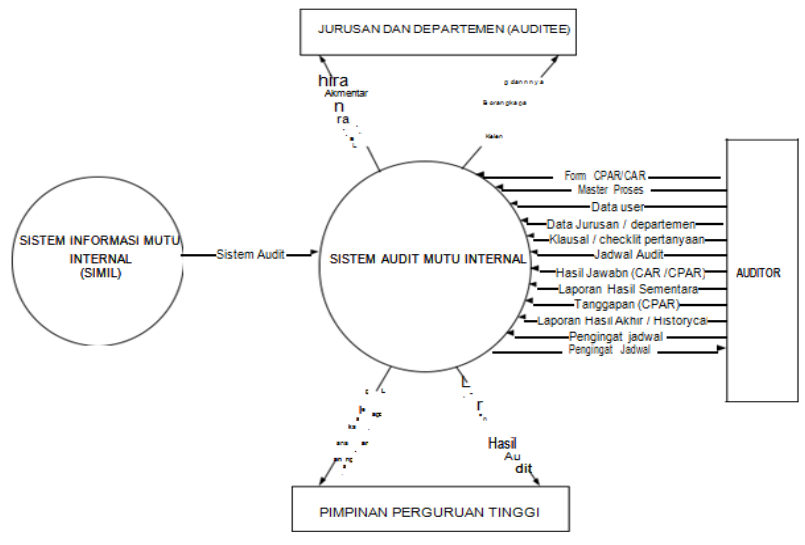

Gambar 2: Rancangan DFD Sistem Informasi Audit

\section{Rancangan Kebutuhan Program}

Proses berjalan yang telah dirancang, seperti perancangan DFD dan tabel checklist pertanyaan berdasarkan kebutuhan program berbasis web antara lain:

1) Level Otorisasi (Akses)

a) Administrator system;

b) Auditor;

c) Departemen termasuk Management Representative; dan

d) Publik terkait SOP bertujuan agar mahasiswa dapat melihat proses akademik yang ada di perguruan tinggi.

\section{2) Check List Audit}

(berisikan daftar pertanyaan memuat klausul standar ISO 90001:2008) dan pertanyaan beberapa butir isian borang sebagai penunjang proses akreditasi, yang berisi antara lain:

a) Dokumen Mutu/Klausul/Butir;

b) Daftar Pertanyaan;

c) Referensi (SOP Unit);

d) Kesesuaian $(\mathrm{Y} / \mathrm{T}) / \mathrm{ada}$ atau tidak adanya temuan;

e) Indikator Sasaran Mutu; f) Referensi Sasaran Mutu (sarmut);

g) Pengukuran ( target dan realisasi);

h) Akar Penyebab/Akar Penunjang (form CAR) (4.FM-C 2.1.01 Form CAR);

i) Rencana Perbaikan dan Tindak Lanjut (form CPAR) (4.FM-A 1.1.01 Form Permintaan Tindakan Perbaikan \& Pencegahan).

\section{3) Dokumentasi}

Dokumentasi ini berisikan bukan hanya dokumen hasil audit saja tetapi dokumen yang terkait dengan sistem proses bisnis di perguruan tinggi antara lain:

a) Quality Manual;

b) SOP;

c) Intruksi Kerja (IK);

d) FM (form); dan

e) Ketentuan (KT)

\section{Implementasi Sistem Informasi Audit}

Penelitian ini menghasilkan sistem informasi audit berbasis web yang sesuai dengan latar belakang dan tujuan yang ingin dicapai. Sistem informasi audit berguna untuk memudahkan pemantau atau evaluasi terhadap pelaksanaan ISO. Selain itu, menu dokumentasi pada sistem audit dapat diakses secara online sehingga mempermudah pihak yang memerlukan dokumen tersebut.

\section{ID SECURITY \\ QWTD4452377-ASP-5244166}

\section{KESIMPULAN}

Sistem informasi berbasis Web menghasilkan daftar checklist berdasarkan klausal ISO 9001:2008 dan Standar SNP bertujuan menghasilkan data serta informasi sistem penjaminan mutu perguruan 
tinggi, panduan, kriteria penilaian, jawaban, laporan, tanggapan dan monitoroting dari temuan berbentuk informasi bagi institusi sebagai faktor atmosfir akademik yang lebih baik;

Sistem informasi audit ini menghasilkan histori dari hasil audit dan pengisian checklist pertanyaan yang dapat di-edit berdasarkan kebutuhan pertanyaan berdasarkan target Key Performance Indicator (KPI).

\section{E. DISKUSI}

Saya bersama teman saya Desi mendiskusikan dengan baik Hasil analisis Implementasi Sistem Informasi Audit implementasi sebuah Penelitian ini menghasilkan sistem informasi audit berbasis web yang sesuai dengan latar belakang dan tujuan yang ingin dicapai dapat disimpulkan sebagai berikut.

1. Perlu ditambahkan kuisioner bagi auditor oleh auditee (teraudit) berguna untuk analisis dan performance dari auditor yang ada;

2. Pada dokumentasi perlu dibuatkan disain seluruh dokumen terkait dengan SOP di perguruan tinggi menggunakan sistem terbuka di web tersebut, contoh menggunakan aplikasi dreamwever untuk memudahkan auditor melihat SOP maupun dokumen lain.

\section{F. REFERENCE}

[1] O. M. Febriani and A. S. Putra, "Sistem Informasi Monitoring Inventori Barang Pada Balai Riset Standardisasi Industri Bandar Lampung,” J. Inform., vol. 13, no. 1, pp. 90-98, 2014.

[2] A. S. Putra, "Paperplain: Execution Fundamental Create Application With
Borland Delphi 7.0 University Of Mitra Indonesia," 2018.

[3] A. S. Putra, "2018 Artikel Struktur Data, Audit Dan Jaringan Komputer," 2018.

[4] A. S. Putra, "ALIAS MANAGER USED IN DATABASE DESKTOP STUDI CASE DB DEMOS.”

[5] A. S. Putra, "COMPREHENSIVE SET OF PROFESSIONAL FOR DISTRIBUTE COMPUTING."

[6] A. S. Putra "DATA ORIENTED RECOGNITION IN BORLAND DELPHI 7.0."

[7] A. S. Putra, "EMBARCADERO DELPHI XE 2 IN GPU-POWERED FIREMONKEY APPLICATION."

[8] A. S. Putra, "HAK ATAS KEKAYAAN INTELEKTUAL DALAM DUNIA TEKNOLOGY BERBASIS REVOLUSI INDUSTRI 4.0.”

[9] A. S. Putra, "IMPLEMENTASI PERATURAN PERUNDANGAN UU. NO 31 TAHUN 2000 TENTANG DESAIN INDUSTRI BERBASIS INFORMATION TECHNOLOGY."

[10] A.S.Putra, "IMPLEMENTATION OF PARADOX DBASE."

[11] A. S. Putra, "IMPLEMENTATION OF TRADE SECRET CASE STUDY SAMSUNG MOBILE PHONE."

[12] A. S. Putra, "IMPLEMENTATION PATENT FOR APPLICATION WEB BASED CASE STUDI WWW. PUBLIKLAMPUNG. COM."

[13] A.S.Putra, "IMPLEMENTATION SYSTEM FIRST TO INVENT IN DIGITALLY INDUSTRY." 
[14] A. S. Putra, "MANUAL REPORT \& INTEGRATED DEVELOPMENT ENVIRONMENT BORLAND DELPHI 7.0."

[15] A. S. Putra, "PATENT AS RELEVAN SUPPORT RESEARCH."

[16] A. S. Putra, "PATENT FOR RESEARCH STUDY CASE OF APPLE. Inc."

[17] A. S. Putra, "PATENT PROTECTION FOR APPLICATION INVENT."

[18] A. S. Putra, "QUICK REPORT

[19] IN PROPERTY PROGRAMMING."

[20] A. S. Putra, "REVIEW CIRCUIT LAYOUT COMPONENT REQUIREMENT ON ASUS NOTEBOOK."

[21] A. S. Putra, "REVIEW TRADEMARK PATENT FOR INDUSTRIAL TECHNOLOGY BASED 4.0."

[22] A. S. Putra, "TOOLBAR COMPONENT PALLETTE IN OBJECT ORIENTED PROGRAMMING.”

[22] A. S. Putra, "WORKING DIRECTORY SET FOR PARADOX 7."

[23] A. S. Putra, "ZQUERY CONNECTION IMPLEMENTED PROGRAMMING STUDI CASE PT. BANK BCA Tbk.”

[24] A. S. Putra, D. R. Aryanti, and I. Hartati, "Metode SAW (Simple Additive Weighting) sebagai Sistem Pendukung Keputusan Guru Berprestasi (Studi Kasus: SMK Global Surya)," in Prosiding Seminar Nasional Darmajaya, 2018, vol. 1, no. 1, pp. 85-97.
[25] A. S. Putra and O. M. Febriani, "Knowledge Management Online Application in PDAM Lampung Province," in ProsidingInternational conference on Information Technology and Business (ICITB), 2018, pp. 181-187.

[26] A. S. Putra, O. M. Febriani, and B. Bachry, "Implementasi Genetic Fuzzy System Untuk Mengidentifikasi Hasil Curian Kendaraan Bermotor Di Polda Lampung," SIMADA (Jurnal Sist. Inf. dan Manaj. Basis Data), vol. 1, no. 1, pp. 2130, 2018.

[27] A. S. Putra, H. Sukri, and K. Zuhri, "Sistem Monitoring Realtime Jaringan Irigasi Desa (JIDES) Dengan Konsep Jaringan Sensor Nirkabel," IJEIS (Indonesian J. Electron. Instrum. Syst., vol. 8, no. 2, pp. 221-232.

[28] D. P. Sari, O. M. Febriani, and A. S. Putra, "Perancangan Sistem Informasi SDM Berprestasi pada SD Global Surya," in Prosiding Seminar Nasional Darmajaya, 2018, vol. 1, no. 1, pp. 289-294. 